\title{
Effects of Urea-Molasses Multi-nutrient Blocks (UMMB) Supplementation on Some Production Parameters of Lactating Horro Cows at Horro Guduru Animal Production and Research Center, Western Ethiopia
}

\author{
Dereje Duressa $^{1^{\star}}$ and Temesegen Bersissa ${ }^{2}$
}

\author{
${ }^{1}$ School of Veterinary Medicine, Wollega University, P.O. Box: 395, Nekemte, Ethiopia \\ ${ }^{2}$ Horro Guduru Animal Production and Research Center, Wollega University, Guduru, Ethiopia
}

\begin{tabular}{|c|c|}
\hline Abstract & Article Information \\
\hline \multirow{12}{*}{$\begin{array}{l}\text { The effects of dietary supplementation of urea-molasses multi nutrient block of lactating } \\
\text { Horro cows fed Rhodes grass (chloris gayana) hay as a basal diet on milk yield, milk } \\
\text { composition, feed intake and live weight change was studied on-station (at Horro Guduru } \\
\text { Animal Production and Research Center of Wollega University). Sixteen cows in similar } \\
\text { parity and lactation were randomly assigned to two groups: group A (control) and group B } \\
\text { (UMMB-supplemented). The control group received baled Rhodes grass hay as a basal } \\
\text { diet and small amount of concentrate; whereas the supplemented group (B) received } \\
\text { UMMB in addition to the normal ration offered to the control group. The experiment was } \\
\text { conducted for } 60 \text { days during the dry months. Mean daily milk yield and feed intake were } \\
\text { higher in the cows supplemented with UMMB ( } P<0.01 \text { ) compared to the un-supplemented } \\
\text { group. The average milk yield for control and supplemented groups are } 1.62 \text { and } 2.38 \\
\text { respectively. On the other hands no significant differences were observed among the } \\
\text { supplemented and control group for milk composition and body weight gain }(P>0.05 \text { ). } \\
\text { However the body weight gain is slightly better for the supplemented group. The increased } \\
\text { milk production due to UMMB supplementation in this study could be attributed to the } \\
\text { increased intakes of energy and nitrogen that was accessed through block } \\
\text { supplementation. }\end{array}$} & History: \\
\hline & Received : 05-01-2016 \\
\hline & : 14-03-2016 \\
\hline & Accepted : 19-03-2016 \\
\hline & Keywords: \\
\hline & UMMB \\
\hline & Rhodes grass \\
\hline & Milk yield \\
\hline & re \\
\hline & rresponding Author: \\
\hline & Duressa \\
\hline & \\
\hline
\end{tabular}

\section{INTRODUCTION}

A major constraint of livestock production in developing countries is the scarcity and fluctuating quantity and quality of the year-round feed supply. In Ethiopia, the communal grazing land is shrinking both in quantity and quality from time to time due to cropping. This calls for the cultivation of improved forages. Various species of improved forages were introduced to Ethiopia through the regular program and projects. Rhodes grass is among the most commonly adapted improved grass species in many parts of the country in general and in the study area in particular. Large amount of baled Rhodes grass hay is being produced and stored as a dry period feed in Horro Guduru Animal Production and Research Center $(H / G / A / P / R / C)$ of Wollega University. The hay is usually offered to the animals with minimal or no supplementation. Urea molasses multi-nutrient blocks (UMMB) have been used as a livestock feed supplement in comparable environments in a number of countries and encouraging results have been reported (Plaizier et al., 1999; Elmansoury et al., 2002; Seyoum and Fekede, 2006). A positive response to dietary urea-molasses multi nutrient block (UMMB) supplementation can therefore be expected for the productive and reproductive performances in local and crossbred dairy cows in different dairy production systems. Large amounts of molasses have been produced as by-product of sugar in four sugar factories in Ethiopia and its supply is expected to substantially increase in the near future due to the expansion of the existing factories and a number of new plants currently under construction and in the planning phase (Adugna, 2007; GTP, 2010).

According to the report of Oromia Livestock and Fisheries Bureau, that the four sugar factories in Oromia alone have a capacity to produce 142733 tons of molasses per annum. This being the case many experiments conducted so far to see the effects of UMMB on production and reproductive performances of cows were mainly focused on cross-breed cows using the locally available feed resources as basal diets. Nevertheless, data are lacking on the effects of UMMBsupplementation particularly on indigenous cattle types like Horro cows with improved forage such as Rhodes grass hay used as basal ration. Therefore, the objective of this study was to evaluate the effect of UMMB supplementation on some production performances of indigenous Horro cows on station by using Rhodes grass hay as a basal feed. Traits under study include milk yield and composition, feed intake and body weight gain. 
Dereje Duressa and Temesegen Bersissa

\section{MATERIALS AND METHODS}

\section{Description of the Study Site}

This study was conducted at Horro Guduru Animal Production and Research Center of Wollega University which is located in Guduru district of Horro Guduru Wollega zone, Oromia National Regional State at about $270 \mathrm{kms}$ west of Addis Ababa with geographical coordinates of $09^{\circ} 29^{\prime} \mathrm{N}$ and $37^{\circ} 26^{\prime} \mathrm{E}$, and at an altitude of approximately 2296 meters above sea level (masl). The mean annual rainfall of the area ranges from 1000-2400 $\mathrm{mm}$ with monthly mean temperatures varying from 14.9 ${ }^{0} \mathrm{C}$ to $17.5{ }^{\circ} \mathrm{C}$ (Tefera, 2006). The center has an area of 764 hectares. Open Nucleus Breeding (within selection) and cross breeding are the two programs underway in the center to improve the indigenous Horro cattle. For these purposes over 2000 cattle are being kept in the farm with all of them are ear tagged. Moreover, many improved forage plants such as Rhodes grass, pannicum and
Sci. Technol. Arts Res. J., Jan-March 2016, 5(1): 35-38

elephant grass are being developed for animal feeding and research purpose. Thus the animals and grass hay used for this study are obtained from the center.

\section{Procedures of UMMB Preparation}

UMMB was prepared at the center with block comprised of formulation, ingredient preparation, mixing, molding, and drying procedures. A rectangular wooden box of dimensions $25 \times 15 \times 10 \mathrm{~cm}$ depth, length and width respectively was used for block production with a single box having a capacity to produce $5 \mathrm{~kg}$ UMMB. The blocks are removed from each box and air dried for $72 \mathrm{hrs}$. The composition of the block was $36 \%$ sugar cane molasses, $10 \%$ urea, $25 \%$ wheat bran, $10 \%$ noug seed cake, $10 \%$ cement, $7 \%$ common salt $(\mathrm{NaCl})$ and $2 \%$ mineral mix. The proportion and purposes of each ingredient is given in table 1.

Table 1: Proportion of ingredients in UMMB (\% by weight)

\begin{tabular}{llrl}
\hline No & Ingredient & \% & \multicolumn{1}{c}{ Purpose } \\
\hline 1 & Molasses & 36 & Provides energy, minerals, improve feed intake \\
2 & Urea & 10 & Provides protein, improve feed digestibility \\
3 & Wheat bran & 25 & Provides protein, hold the block together \\
4 & Noug seed cake & 10 & Source of protein \\
5 & Cement & 10 & Provides Ca, makes the block hard \\
6 & Salt & 7 & Supply minerals, control rate of consumption \\
7 & Mineral mix & 2 & Supply minerals \\
\hline & Total & $\mathbf{1 0 0}$ & \\
\hline
\end{tabular}

\section{Management of the Experimental Animals}

A total of 16 lactating Horro cows having similar parity $\left(1^{\text {st }}\right.$ and $\left.2^{\text {nd }}\right)$, lactation stage, and age and body condition (score 2-3) were used for the study. The cows were selected from the herd of the research center. The experimental cows were completely and randomly divided in to two groups A (control) and B (UMMB-supplemented) with 8 cows in each group.

\section{Adaptation Period of UMMB}

Ten days adaptation period was given followed by 60 days experimental period. All cows in both groups were dewormed against common helminthes and vaccinated against common diseases (Anthrax and bovine pasteurellosis) before the actual experiment. The experimental cows (group B) were supplemented with UMMB at the dose rate of $250 \mathrm{~g} /$ day/animal during the adaptation period.

\section{On-station trial}

The study was conducted in Horro Guduru Animal Production and Research Center of Wollega University between the dry months of February 10 to April 10, 2015. Baled Rhodes grass hay of the center was used as a basal diet for both groups with small amount of concentrate. Accordingly, each cow offered 4.5 and $1.5 \mathrm{~kg}$ of Rhodes grass hay and concentrate/day respectively. All animals were stalled under roofed shed with concrete floor and feeding was on individual basis. Clean water was provided adlibtum for both groups during the experimental period. The animals in group $B$ received UMMB supplement in addition to the basal feed. Blocks were supplied to individual animals in a plastic (jerican) cut in a rectangular shape for proper licking. Cows were allowed to lick the blocks from 8:00 am to 5:00 pm after which the blocks are collected.

\section{Data Recording \\ Feed Chemical Composition}

The chemical composition of feed samples were analyzed at Holeta research center for dry matter (DM), crude protein (CP), ash, acid detergent fiber (ADF), neutral detergent fiber (NDF) and lignin content using standard methods and procedures. In addition in-vitro digestibility of each feed sample was determined.

\section{Milk Yield, Feed Intake and Body Weight Measurements}

All cows were hand milked twice daily in the morning and evening at about 8:00 am and 5:00 pm respectively. Milk yield was recorded in the morning and evening on daily basis for individual cows. Feed offered and refused was recorded daily and composited for analysis. The weight of all lactating experimental animals (empty stomach) was taken at the start of the experiment using heart girth meter. Thereafter, the body weights were recorded on a weekly basis. The reading of heart girth (as an indirect estimation of body weight) was converted to $\mathrm{kg}$ using the regression equation (Addisu, 2010).

Body weight in $(\mathrm{Kg})=2.126^{*}$ heart girth $(\mathrm{cm})-87.39$.

\section{Milk composition}

Milk samples from both groups were analyzed for constituents (protein, fat, total solids, solids not fat (SNF) and ash at Holeta research center.

\section{Statistical analysis}

Data collected on milk yield and composition, feed intake, estimated body weight, and feed chemical 


\section{Dereje Duressa and Temesegen Bersissa}

composition was analyzed using the Mixed Linear Model procedure of SAS 9.2 (2009).

\section{RESULTS AND DISCUSSION}

\section{Feed Chemical Composition}

As indicated in table 2 the crude protein content of the Rhodes grass hay used as a basal diet (7.08) is nearly equivalent to the results $(7 \%)$ by Tolera (2008) but higher than the value (3.2\%) reported by Nurfeta, and Getiso, (2008). Tesfaye, (2014) reported the CP values of 34.5
Sci. Technol. Arts Res. J., Jan-March 2016, 5(1): 35-38

and $16.8 \%$ for noug seed cake and wheat bran respectively. On the other hands the hay had higher NDF and ADF contents indicating the poor nutritional potential of the hay to meet the maintenance and production requirements of lactating cows. Correspondingly in-vitro dry matter digestibility (IVDMD) of Rhodes grass was lower than that of wheat barn and noug seed cake depicting that supplementation of UMMB is of paramount importance to supply the required amount of $\mathrm{N}$ for the rumen microbes which in turn improve feed digestibility.

Table 2: Chemical composition of feeds offered

\begin{tabular}{lllllllll}
\hline No & Feedstuff & DM & Ash & CP & NDF & ADF & Lignin & IVD \\
\hline $\mathbf{1}$ & Rhodes Grass & 91.71 & 9.19 & 7.08 & 70.22 & 37.83 & 4.86 & 55.81 \\
$\mathbf{2}$ & Concentrate & 92.02 & 9.1 & 17.79 & 36.45 & 11.22 & 2.91 & NA \\
$\mathbf{3}$ & Wheat bran & 93.39 & 4.93 & 15.75 & 48.15 & 14.85 & 3.91 & 75.89 \\
$\mathbf{4}$ & Noug seed cake & 93.27 & 9.39 & 33.55 & 31.15 & 30.85 & 12.57 & 61.26 \\
$\mathbf{5}$ & Molasses & 74.96 & NA & 2.7 & 36 & NA & NA & NA \\
\hline \multicolumn{7}{c}{ Where, DM = Dry Matter; CP = Crude Protein; NDF = Neutral detergent Fiber; } \\
ADF = Acid Detergent Fiber; IVD = In-vitro Degradability; NA = Non-analysis.
\end{tabular}

Effect of UMMB on Milk Yield, Milk Composition and Body Weight Change

The effect of UMMB supplementation on milk yield of indigenous lactating Horro cows is indicated in table 3. The average daily milk yield prior to the experiment was 1.04 and 1.07 liters for Group A (non-supplemented) and $B$ (supplemented) respectively. During the experimental period of 60 days the average daily milk yield for control (group A) and treated (group B) were 1.62 and 2.38 liters respectively depicting that supplementation of UMMB showed significant effects $(P<0.01)$. Similar results were reported by (Yeasmin et al., 2004) who evaluated the effect of UMBB supplementation on dairy cows that fed rice straw and green grass. According to NKYA et al.
(1997), on-station cows receiving adlibitum grass hay and $6 \mathrm{~kg} / \mathrm{d}$ of maize bran supplemented with UMMB resulted in increased milk production from $6.7 \mathrm{~L} / \mathrm{d}$ to $11.2 \mathrm{~L} / \mathrm{d}$ $(P<0.01)$ but did not significantly affect milk composition and live weight change. In the current study, there was no significant differences between the UMMB supplemented and control group for protein and fat composition of the milk samples (Table 4). However the milk sample from the UMMB-supplemented group contained a slightly better protein $(3.46 \%)$ and fat (6.20\%) vis-à-vis the control group for which $3.06 \%$ protein and $6.0 \%$ fat was recorded. The increased milk production due to UMMB supplementation in this study could be attributed to the increased intakes of energy and nitrogen.

Table 3: Milk yield, feed intake and change in body weight

\begin{tabular}{lccccc}
\hline \multicolumn{1}{c}{ Parameters } & $\begin{array}{c}\text { Group A } \\
\text { (control) }\end{array}$ & $\begin{array}{c}\text { Group B } \\
\text { (supplemented) }\end{array}$ & Mean & $\begin{array}{c}\text { Standard } \\
\text { error (SE) }\end{array}$ & $\begin{array}{c}\text { Significance } \\
\text { level }\end{array}$ \\
\hline Ave. milk yield (Lit/day) & 1.62 & 2.38 & 2.00 & 0.03 & $* \star *$ \\
Ave. feed intake (kg) & 180.91 & 199.14 & 190.03 & 2.40 & $* \star$ \\
Ave. initial weight (kg) & 197.97 & $198 . .03$ & 198.00 & 6.27 & NS \\
Ave. final weight $(\mathrm{kg})$ & 201.75 & 204.40 & 203.02 & 4.61 & $\mathrm{NS}$ \\
\hline
\end{tabular}

Table 4: Milk Composition of experimental cows

\begin{tabular}{lccccc}
\hline Constituents & Group A & Group B & Mean & SE & Significance level \\
\hline Protein (\%) & 3.06 & 3.46 & 3.26 & 0.07 & NS \\
Fat (\%) & 6.00 & 6.20 & 6.10 & 0.13 & NS \\
Total Solid (\%) & 16.02 & 15.98 & 16.00 & 0.15 & NS \\
Ash (\%) & 0.74 & 0.78 & 0.76 & 0.03 & NS \\
SNF (\%) & 10.02 & 9.78 & 8.90 & 0.15 & NS \\
\hline
\end{tabular}

\section{Effect of UMMB on Feed Intake}

Supplementation of UMMB showed highly significant differences on feed intake $(P<0.01)$ between the supplemented and control group (Table 3). Tekeba (2012) also reported significant effects of UMMB on the feed intake of Fogera cattle that were in their mid lactation. The increase in feed intake in the current study might be related to higher palatability of diet due to inclusion of the block, and might be due to the fact that molasses feed the rumen bugs which result in higher degradation of fibrous diet. The lower feed intake of the un-supplemented group might be associated with the high NDF content of the basal hay as NDF is the major component limiting rumen fill, and directly correlated with rumination or chewing time (Cheeke, 1999).

\section{Effect of UMMB on Body Weight Gain}

The average initial average live weight of lactating cows before block licking in the control group (group A) and experimental group (group B) was $197.97 \mathrm{~kg} 198.03$ 


\section{Dereje Duressa and Temesegen Bersissa}

$\mathrm{kg}$ respectively. The averaged final live weight of all cows in the supplemented and in control group was 201.75 and $204.40 \mathrm{~kg}$ respectively. Though there was an expectation that UMMB would have significantly improve the weight gain of the treated cows, there was no significant difference observed between control and the treated group but better live weight gain was recorded for the UMMB group. Contrary to this finding (Tekeba, 2012) reported significant improvements in estimated body weight gain of Fogera (121\%) and crossbred cows (97\%) due to UMMB supplementation. The findings of this study is also not in agreement with that of (Ghosh et al., 1993; Alam et al., 2009) who reported the significant effects of UMMB on daily body weight gain of local cows. The increase in body weight gain of the supplemented cows, though not significantly different, suggests the positive effects of UMMB in improving the body condition of animals.

\section{CONCLUSIONS}

Dry period supplementation of UMMB to lactating Horro cows fed Rhodes grass hay as basal diet resulted in improved milk yield and feed intake $(P<0.01)$ whereas body weight gain and milk composition were not significantly affected. Rhodes grass is among the improved forages popularized in the study center as well as by farmers in the study area. The availability of molasses in the locality in abundant quantity with fair price would be an opportunity for wider use in the future. To this end similar trials need to be conducted at farmers' level by using the findings vitalized in this study including the economic aspects of block supplementation.

\section{Conflict of Interest}

No declared

\section{Acknowledgements}

The Authors wish to thank the Research and technology transfer office of Wollega University for their financial support and Horro Guduru Animal production and Research Center staffs for their technical assistance. Moreover Holeta Research Center shall deserve special thank for its laboratory supports.

\section{REFERENCES}

Addisu, B. (2010). Preliminary report on prediction of body weight of Fogera cattle from heart girth measurements. Andassa Livestock Research Centre. North-western Ethiopia.

Adugna, T. (2007). Feed Resources for Producing Export Quality Meat and Livestock in Ethiopia. Examples from Selected Woredas in Oromia and SNNP Regional States, Ethiopia, 88p. http://www.igad-data.org/index.php

Alam, M.G.S., Rahman, M.A., Khatun, M., Ahmed, T.U. (2009). Feed supplementation and weight change, milk yield and post-partum oestrus in desi cows. Bangladesh Veterinarian 26(2): 39-47.
Sci. Technol. Arts Res. J., Jan-March 2016, 5(1): 35-38

Cheeke, P.R. (1999). Applied animal nutrition: Feeds and Feeding. $2^{\text {nd }}$ ed., PrinceHall, Inc., new Jersey.

Ghosh, A., Alam, M. G. S., Akbar, M. A. (1993). Effect of urea-molasses-mineral block supplementation on postpartum ovarian activity in zebu cows. Anim. Repr. Sci. J. 31, 61-67.

GTP (2010). Growth and Transformation Plan 2010/112014/15 Draft. The Federal Democratic Republic of Ethiopia Ministry of Finance and Economic Development, Addis Ababa Ethiopia, 16-18.

Nkya, R., Shem, M.N., Urio, N.A. (1997). Dry season supplementation of dairy cows with urea molasses mineral blocks and molasses-urea mix in the Morogoro region in Tanzania. Sokoine University of Agriculture, Morogoro, Tanzania.

Nurfeta, A. and Gutiso, A. (2014). The nutritional value of (enset) kocho as an alternate concentrate for sheep fed Rhodes grass hay. Ethiopian Journal of Animal Production 14(1): 34-50.

Sarwar, M. and Khan. M. A. (2004). Effect of organic acids or fermentable carbohydrates on digestibility and nitrogen utilization of urea treated wheat straw in buffalo bulls. Crop and Pasture Science 55(2): 223-228.

SAS (Statistical Analysis System), (2009). SAS/STAT User's Guide, version 9.2. Cary, NC, USA.

Tefera, O.B. (2006). People and Dams: Environmental and socio-economic changes induced by a reservoir in Fincha'a watershed, western Ethiopia. PhD Thesis, Wageningen University, The Netherlands.

Tekeba. E. (2012). Effects of dietary supplementation with Urea Molasses Multi-Nutrient Block in local Ethiopian and crossbred dairy cows in North-western Ethiopia. Doctoral Thesis.

Tekeba, E., Wurzinger, M and Zollitsch, W (2012). Effects of urea-molasses multi-nutrient blocks as a dietary supplement for dairy cows in two milk production systems in north-western Ethiopia. Livestock Research for Rural Development 24(8).

Tesfaye, H. (2007). Supplementation of Afar rams with graded levels of mixtures of protein and energy sources: Effects on feed intake, digestibility and live weight and carcass parameters. An MSc Thesis Presented to the School of Graduate Studies of Haramaya University of Agriculture, Ethiopia.

Tolera, A. (2008). Feed resources and feeding management: a manual for feedlot operations and development workers. SPS-LMM program, Addis Ababa, Ethiopia.

Yeasmin Akter., M.A Akbar., M. Shahilal., and T.U. Ahmad,. (2004). Effect of Urea Molasses Multi-nutrient Blocks Supplementation of Dairy cows fed rice straw and green grass on milk yield, composition, live weight gain of cows and calves and feed intake. http://agris.fao.org/agrissearch/search.do?recordID=PK2004001203 